\title{
ARACELI IRAVEDRA, HACIA LA DEMOCRACIA. LA NUEVA POESÍA (1968-2000), MADRID, Colección Visor de Poesía, 2016, 1085 Pp.
}

Comenzando en el emblemático y decisivo año de 1968, hasta alcanzar las últimas tendencias poéticas en el filo mismo de la segunda década del siglo XXI, la antología crítica Hacia la democracia. La nueva poesía (1968-2000) está destinada a convertirse en una obra de referencia para poetas, críticos, docentes, estudiantes y lectores en general. Publicada en la ya clásica Colección Visor de Poesía («Poesía Española», Volumen 10) y con la colaboración y el respaldo del Centro para la Edición de los Clásicos Españoles, se trata de un ambicioso proyecto que destaca tanto por su envergadura, como por su solvencia experta; aunando ahí la vocación divulgativa, la utilidad didáctica y una voluntad crítica honesta y rigurosa al enfrentarse, y poner orden, en uno de los periodos poéticos más complejos, más inestables -tal vez por su cercanía- y más polémicos de nuestra historia, también literaria: la dificilísima salida de una dictadura de 40 años y la entrada y posterior normalización de nuestro actual sistema parlamentario democrático.

Ha sido un gran acierto de la editorial Visor poner a cargo de este proyecto a la profesora Araceli Iravedra, titular de la Universidad de Oviedo; un referente en los estudios sobre la poesía del medio-siglo español y ampliamente reconocida por sus valiosas aportaciones al debate, siempre fascinante, sobre el «compromiso» literario; una perspectiva que -en mi opinión-es la más adecuada, la más capaz de iluminar la moderna democratización ideológica de la poesía española desde sus orígenes mismos en las décadas de 1950 y 1960. En este sentido, la antología llega, además, en un momento 
importante; uno en el que se acumulan ya muchas promociones y grupos poéticos; en el que ya se ha visto nacer, desarrollarse y decaer a muchas corrientes y estilos; un momento convulso y movedizo, auténtico rompeolas histórico, ausente de grandes certezas y en la búsqueda de referencias culturales y relatos que vayan explicando (y explicándonos) nuestro pasado poético reciente y aclarando sus claves también para los lectores del futuro. Esta es, sin duda, la mejor contribución de un libro que será ya imprescindible en esa tarea.

Uno de los aspectos siempre más problemáticos y más arriesgados de las antologías panorámicas, como ésta, ha sido siempre -y seguirá siempre siendo- la selección de autores y textos. Si la amplitud del proyecto garantiza un margen amplio de representatividad, la profesora Iravedra realiza en este punto un trabajo minucioso, especialmente destacable. Los treinta y cuatro autores consagrados son todos ellos necesarios (pienso quizá, y ya personalmente, que también hubiera cabido ahí la obra de Javier Egea); en su práctica mayoría, verdaderos clásicos, imprescindibles para comprender cabalmente la evolución de nuestra poesía y el establecimiento de su canon; trazado de un recorrido que iluminará a cualquier interesado. Cada poeta es comentado y descubierto, además, en su propia lógica interna - se incorporan utilísimos materiales biobibliográficos, plenamente actualizados-, sobre una muestra generosa de sus piezas más importantes en el tiempo, las más emblemáticas y representativas de su propia tendencia y sensibilidad; todas ellas comentadas en un aparato crítico especialmente destacable por su precisión filológica.

En rigor, el gran lienzo poético dibujado por la profesora Iravedra encuentra su justificación y su pleno sentido en el prólogo (todo un auténtico estudio crítico) que introduce el libro. Encontrará el lector ahí un planteamiento bien equilibrado de todos los debates significativos que han determinado históricamente la trayectoria de nuestra poesía actual. Quiero subrayar, en particular, la dificultad verdadera de organizar su variadísimo conjunto en una estructura analítica tan compacta, coherente y alumbradora; ahí perfectamente resuelta. El estudio evita deliberadamente caer en la simplificación y las reducciones, en los aburridísimos antagonismos que parecen dominar la pedagogía de nuestro arte (útiles, tal vez, para capturar una eventual instantánea; pero muy expuestos y poco favorables al intercambio). Las antologías panorámicas y generalistas no suelen ser, normalmente, lugares propicios para discutir; pero precisamente en el periodo democrático, y siempre más - por la profundidad de sus implicaciones- en la perspectiva poética, el tablero de la discusión debe abrirse, como aquí lo hace, a la polémica y el contraste de ideas: con el máximo rigor científico, la poesía noblemente entendida como espacio donde se dirimen y se ponen en movimiento - 
muchas veces encontrándose- conceptos altamente complejos que afectan a la base misma de nuestra cultura, a nuestra relación con el tiempo, con la realidad alrededor y con "los otros". Sin perder de vista las condiciones específicas, tan particulares, de la industria literaria y sus mecanismos de producción, el estudio se desenvuelve convincentemente entre debates técnicos peritos - bien planteados $\mathrm{y}$ bien compendiados para facilidad del lector-, como, por ejemplo, las diferentes ópticas, concepciones y cosmovisiones ideológicas de la poesía (también, en algún caso, incluso estrictamente políticas), las diferentes interpretaciones de la tradición, los diferentes usos y «prácticas» del propio lenguaje o las discusiones sobre el lugar ocupado por la poesía en nuestra sociedad; por otro lado, también descendiendo a los análisis más detenidos de aquellas obras y antologías históricamente relevantes para la comprensión de su progreso y sus transformaciones.

Entre todos los momentos poéticos analizados, con rigor verdadero y gran detalle, hay algunos particularmente controvertidos e interesantes a los que quisiera prestar aquí una atención especial. Uno de ellos se refiere al nacimiento mismo y la indagación de los orígenes democráticos de nuestra poesía; debate difícil, bien planteado y bien dominado por la profesora Iravedra, que plantea un inevitable «pecado (histórico) original» del que, acaso, ya no podamos liberarnos nunca. En verdad, por más que las condiciones y circunstancias de la dictadura española hubieran cambiado y evolucionado desde los ya lejanos años cuarenta, el hecho de que parte de la crítica literaria hable de «post-franquismo» en el año 1968 —casilla de salida del estudio-, no parece apropiado. Tal vez, con mayor deontología, podría hablarse de «tardofranquismo» para evitar confusiones innecesarias. Porque cabe entender (y es legítimo) que, frente a un realismo cansado $\mathrm{y}$ en franca dispersión, los entonces jóvenes poetas novísimos desarrollaran su particular idea «moderna» del arte literario, abiertamente vinculándola con la tradición liberal y simbolista clásica (desde Manuel Vázquez Montalbán, hasta Pere Gimferrer). Sin embargo, ni siquiera desde el más puro de los idealismos poéticos, es posible justificar la «desaparición» de Franco con una década de antelación; argumento habitualmente utilizado como línea de defensa para justificar, en el mejor de los casos, algunos escapes de la realidad española del momento. Movimiento ampliamente dominante hasta los años 1977-1978, los novísimos son desplazados del centro (poético) histórico aproximadamente coincidiendo con las nuevas elecciones democráticas; y ello a pesar de sus reiterados esfuerzos por reaparecer (primera y segunda generación novísimas; una, dos y hasta tres «mutaciones»; incluso toda una ambigua promoción «post-novísima» extendida, casi sin término, por todo el fin-de-siglo) en un escenario al que, tal vez, ya aportaban poco. Será, en verdad, como así es señalado en el estudio, en la heterogeneidad, en la variedad y en la pluralidad de propuestas 
de los años ochenta cuando la poesía española se sitúe ante las verdaderas complejidades planteadas por el sistema democrático -ahora sí- post-franquista y su nuevo paradigma literario: la auténtica lucha, seria, responsable y tranquila (ya en libertad), por el establecimiento de $L a$ Norma.

De entre los estilos y obras poéticas que aparecen entonces (clasicismo, neoromanticismo, simbolismo; siempre en distintas líneas) se va consolidando lentamente la hegemonía de un -alguna vez llamado- «realismo singular»; un regreso lúcido a la referencialidad y a lo figurativo, cada vez más inclinándose por la exploración autobiográfica, el distanciamiento y el tono confesional que traslada la tradición del monólogo dramático asentada por Robert Langbaum ( $\mathrm{y}$, entre nosotros, por Jaime Gil de Biedma): lo que es ya, de hecho, el nacimiento de la Poesía de la experiencia. Sobresaliente en nuestra lírica durante más de una década, los pormenores de su proceso de configuración histórica -sus fortísimas tensiones internas; sus respuestas organizadas-constituyen uno de los mapas de situación más completos escritos hasta la fecha sobre el movimiento (muy necesitado de organización crítica) y remito a su lectura de manera entusiasta. Surgidos en origen de los presupuestos de La otra sentimentalidad de Granada (luego matizados y contenidos, según el lugar y la tradición donde se instalan), la ironía, la relación entre el «yo» y la ciudad, la dramatización de lo cotidiano, la -intensamente buscada- seducción del lector, han sido los centros operativos de una poesía «normalizada», extendida por toda la geografía española, que habla con elocuencia de las preferencias del público promedio durante los años noventa y de nuestra democracia misma: su modelo de vida, su lógica lingüística, su ideología escéptica y fuertemente antiutópica; la manera, al fin, de entenderse a sí mismos, más allá siempre de las poderosas otras alternativas -neosurrealistas, metafísicas o radicales- que se levantaron contra ella, usualmente bajo la acusación de autocomplacencia, «pacto con la facilidad» o conformismo. Asediada la «experiencia» desde diversos frentes tanto realistas, como simbolistas-, desde 1995 se hacen ya manifiestamente visibles sus grietas históricas (incluyendo un capítulo brillante dedicado al compromiso poético post-moderno), dando ya paso al escenario abierto y algo confuso que se dibuja en la actualidad entre los jóvenes: fuertes crisis identitarias y desconfianza ante la realidad; traducido todo en una notable tendencia a la fragmentación y la extrañeza -rasgos, tal vez, acentuados tras la crisis de 2008-; pero también su decidida vocación mestiza, su excelente dominio técnico y perito (sin necesidad de exhibiciones narcisistas), así como una asimilación mucho más natural y menos aparatosa de las tradiciones y referentes internacionales que, entre otros, constituye uno sus elementos más positivos y prometedores. Rigurosa, al, fin, auténticamente alumbradora, altamente recomendable, la antología crítica Hacia 
la democracia. La nueva poesía (1968-2000), nuevo límite crítico en el análisis de la no solo resulta una herramienta útil para poesía española de nuestros días: su más iniciarse y útil para los iniciados; sino actualizado mapa histórico hasta la fecha. que adelanta también y consolida un 